\title{
IMPLICATION OF PAK-INDIA TRADE RELATIONSHIP ON PHARMACETICAL AND AUTOMOBILE AND ECONOMY OF PAKISTAN BY USING COMPUTABLE GENERAL EQUILIBIUM MODEL (CGE) Model
}

\author{
Dr.Faiz.M.Shaikh \\ Assistant Professor \\ SZABAC-Dokri-Larkana-Sindh \\ Pakistan \\ Email:faizs045@gmail.com \\ Dr.Anwar Ali Shah G.Syed \\ PVC-Sindh University Campus Dadu \\ Dr. Abdullah Sethar \\ Deputy Project Director, \\ Sindh Agricultural Growth Project ( Livestock Component) \\ World Bank Assisted, Government of Sindh, -Sindh

\section{Dr.Muhammad Ali}

\section{Assistant Professor-IBA-Sukkur}

\begin{abstract}
This research investigates the Impact of PAK-INDIA trade on Economy of Pakistan. Data were collected from GTAP-7 database and six sectors were included in the database, Textile, Pharmaceutical, Automobile parts and engineering, Agriculture, Financial and Insurance services and logistics. Data were analyzed by using GEM-software. Different simulation run on GTAP-7 database and various tariff rates applied. It was revealed that if India were removing the sensitive list item, in this scenario both countries would have positive impact on GDP, Export, Import and Employment of Pakistan. The results indicates that there in Agriculture, textile, Auto Pakistan's is head on India in MFN status. In Pharmaceutical, Financial services and Logistics India has positive gain. It was further revealed that if Pakistan is given MFN status to India, Pakistan's import decreased and Export increased and overall positive impact on Economy. This research analyzes the potential economic costsand benefitsof Pak-India trade in Textile, Pharmaceutical, Automobile parts and engineering, Agriculture, Financial and Insurance services and logistics.

Thefirstscenariois whennormaltradingrelationwithIndiawillberestored;it meansthat bothcountries will give theMFN (Most FavoredNations)statustoeach other. Inthesecondscenario,the SAFTAwill beoperativeandthere will be freetrade between IndiaandPakistanandbothcountrieswill remove all tariffsandcustom dutiesfrom eachothers'imports. TheGlobal tradeanalysisGTAPmodelisusedtoanalyzethe possibleimpactofSAFTAonPakistaninamulticountry,multisectorappliedGeneral equilibrium framework.After employingthe simplifiedstaticanalysisframework,theanalysisbasedonsimulationsrevealsthatcurrentdemandfor PakistaniTextile, Pharmaceutical, Automobile parts and engineering, Agriculture, Financial and Insurance services and logistics willexpandaftertheFTAand consumersurplus willincrease.Thedropinthedomesticpricesofdates willincreasethe production ofmany downstream industries, whichwillhave pleasantmultipliereffectsontheeconomyofPakistan. Thegovernmentmay reduceMFNtariffsonindustrialdatesbeforeimplementingtheFTA.
\end{abstract}

Key Words-PAK-INDIA, TRADE, CGE.

\section{Introduction}

Trade liberalization was the key component of this new strategy bundle and it involved dependence on taxes, substitution of quantitative limitations including import authorizing by a changed arrangement of duties and in addition the unwinding of different controls on exchange. Keeping in mind the end goal to support both local and remote venture, the Government offered a progression of impetuses, while endeavoring to make a domain helpful for speculation. Lately, be that as it may, the center of Pakistan's exchange arrangement has apparently moved towards regionalism, which Pakistan considers a springboard for more extensive exchange liberalization. The method of reasoning for local collaboration depends on various variables, not all of which are essentially financial in nature. Until the late 1970s, Pakistan's financial improvement focused on an internal situated advancement system in view of import substitution industrialization performed for the most

\begin{tabular}{|c|c|}
\hline $\begin{array}{l}\text { 2936 |P a g e } \\
\text { A u g u s t } 2016\end{array}$ & $\begin{array}{r}\text { council for Innovative Research } \\
\text { w w w c irworld. com }\end{array}$ \\
\hline
\end{tabular}


part by state claimed firms. Both duty and non-tax boundaries were generally used to secure household financial exercises. Exchange prohibitive approaches were joined by other administrative arrangements, for example, control on remote trade, fund and outside direct venture. These prohibitive monetary arrangements had serious unfavorable ramifications on general financial development, specifically development of fares. Pakistan presented broad monetary changes in 1971-72 turning into the principal nation in the South Asian area to do as such. The economy was liberated from the internal situated methodology, and embraced an outward-arranged fare drove advancement procedure, which was trailed by numerous East Asian nations around then. This exploration starts with a survey of Pakistan's monetary changes and their scope. The strategy, will offer a brief depiction of CGE Modeling including the GTAP. At that point we will examine test outlines are talked about. Through the model we frame one-sided and territorial exchange liberalization, as an establishing individual from the WTO, Pakistan as a part immovably dedicated to the multilateral exchanging framework and has as of now build up an extensive number of changes with regards to the GATTMTO standards. In any case, this study will audit the result of multilateral exchange Liberalization. The GTAP model reproduction will be broke down.

\section{Research Problem}

The development of EU, NAFTA, MERCOSUR and ASEAN, and the late rise of other provincial exchanging coalitions may have offered ascend to a recovery of enthusiasm for regionalism in Pakistan. This likewise discloses the nation's yearning to keep away from underestimation as more nations get to be individuals from different RTAs, (Baldwin, 1993). Further, a RTA encourages the decision of a specific liberalization approach as commonly concurred by all part economies, keeping them shielded from worldwide rivalry. Along these lines, Pakistan proceeded to 5 advance global exchange through dynamic interest in a few local exchanging assentions, for example, South Asian Preferential Trading Agreement (SAPTA), 7 India-Sri-Lanka Free Trade Agreement (ILFTA), 8 Bangkok Agreement (BA) 9, the Bay of Bengal Initiative for Multi sectorial Technical and Economic Cooperation (BIMST-EC) 10 containing Bangladesh, India, Myanmar, Pakistan and Thailand and Indian Ocean Rim Association for Regional Cooperation (IORARC). The Free Trade Agreement (FTA) between Pakistan (PLFTA) got to be operational from June 2005. SAFTA was the main real stride in moving towards a facilitated commerce range and higher types of provincial financial mix among the part conditions of the South Asian Association for Regional Cooperation (SAARC). Part nations comprising of Bangladesh, Bhutan, India, Maldives, Nepal, Pakistan and Pakistan built up SAARC in 1985. The SAAC individuals, giving a legitimate structure to exchange liberalization and fortifying intra-local monetary collaboration, consented to the arrangement on SAFTA in Dhaka in April 1993. In 1995, SAFTA had been endorsed by all contracting states and as per Article 22 of the assention SAFTA got to be operational on seventh December 1995. SAFTA took after a positive rundown approach, including adaptable procurements for minimum created nations (LDCs). At the Ninth SAARC Summit held in Male in 1997, the Heads of Governments chose to quicken the pace of move of SAFTA to South Asian Free Trade Agreement (SAFTA) by the year 2001 or Consumption is likewise very high amid Christmas. Also, the organic product appreciates colossal hugeness on the event of Dial and such celebrations another religion. In Europe and North America, the natural product is especially favored amid the dull winter month. Normal offers of dates are spread to a period from October to April. The ebb and flow research concentrate on Pak-India exchange relationship on moving towards MFN.

Targets

The targets of the present study are to examine and evaluate the potential financial cost and advantages of the forthcoming exchange amongst India and Pakistan Trade on GDP, Employment, Export and Imports.

To break down the Welfare impacts of host nation on Pak-India Trade

To investigate the welfare pick up/misfortune on MFN

To decide the effect on the economy of Pakistan

\section{Writing Review}

Local exchange assentions (RTAs) have developed as an other option to accomplish exchange liberalization as multilateral endeavors have confronted political and monetary obstacles.2,3 The challenges of achieving concurrences on touchy issues like farming and administrations have been apparent in the Doha Round. The past rounds were additionally set apart by mind boggling and moderate transaction forms. For one, as the quantity of members expands, it has been more hard to address every nation's requests for uncommon contemplations.

RTAs pass on focal points and in addition impediments. By lessening the quantity of members in the transaction they can extend the dialog to incorporate more measurements of monetary combination. 
International Journal of Management and Information Technology

Contrasted and one-sided liberalization, political backing for RTAs additionally is by all accounts more prominent given the view of correspondence from other part nations. Nonetheless, since the early work of Viner (1950), these advantages have been weighted against bends that RTAs can make. By accepted oppressing nonmembers, RTAs twist asset assignment, favoring territorial makers to the potential inconvenience of neighborhood shoppers. Late research additionally stresses the worldwide results of various and covering RTAs regarding the exchange costs they force (Feridhanusetyawan, 2005).

In spite of the fact that RTAs have fluctuated segments, these assentions incorporate a few or the majority of the accompanying eight components (Bhagwati and Panagariya, 1996 give a review): (i) a duty liberalization program-TLP (change of nontariff boundaries, e.g. quantities, to their duty proportionate and the successive diminishment of duties; unique contemplations to slightest created countries4 are not extraordinary); (ii) delicate records (merchandise or administrations to be excluded from the tax decrease program);5 (iii) principles of inception-ROO (anticipation of the utilization of the particular levies to non territorial products or administrations as characterized by the agreement);6 (iv) institutional game plans (foundation of a gathering or regulatory board of trustees in charge of the organization and usage of the assention); ( $v$ ) exchange help arrangements (accumulation of instruments to lessen exchange expenses of importing and The writing about exchange understandings is rich in acronyms that mean either their land augmentation or their level of exchange hindrance diminishments. RTAs allude to assentions including territorial accomplices. Unhindered commerce Agreements (FTAs) alludes to assentions that incorporates the full end of duties (and exchange obstructions) while Preferential Trade Agreements (PTAs) s allude to understandings including fractional duty end. For instance, SAPTA is South Asia's PTA and SAFTA is South Asia's FTA.Exporting, including homogenization of traditions practices and specialized help uncommonly to the minimum created individuals); (vi) debate settlement instrument (systems to report and manage infringement to the assention); (vii) shields measures (suspension of particular treatment on grounds that imports are bringing about or undermining to bring about genuine harm to the local mechanical base); and (viii) parallel lessening in outside speculation boundaries and/or exchange administrations.

South Asia (Bangladesh, Bhutan, India, Maldives, Nepal, Pakistan and Sri Lanka) has been involved in setting up its own RTA. The South Asian Association for Regional Cooperation(SAARC) was formed in 1985 with the objective of exploiting "accelerated economic growth, social progress and cultural development in the region" for the welfare of the peoples of South Asia (SAARC Secretariat, 2006). In 1995, its corresponding RTA (SAPTA) came into force. South Asian Free Trade Agreement (SAFTA) has been ratified and entered into force in mid2006. In comparison to other African countries, over the past two decades attention of researchers, government, and donors has been focused in Kenya's horticultural and floriculture sectors due to their capacity to grow rapidly and yet sustainably to meet international standards (Jaffee, 2004). The production highly oriented to export markets can be track back at the farm level. While over $90 \%$ of smallholder farmers in all but the arid regions of Kenya produce horticultural products, less than $8 \%$ cultivate other kind of crops (Tschirley, et al, 2004). SAFTA is expected to increase regional trade (trade creation) but may do so at the expense of trade flows from more efficient non regional suppliers (trade diversion). Baysan and others (2006) argue that it is unlikely that the most efficient suppliers of the member countries are within the region. Based on that and on the restrictiveness of SAFTA's sensitive lists and rules of origin, it concludes the economic merits of SAFTA are "quite weak." Using the static general equilibrium methodology, Bandara and $Y u(2003)$ find that the full elimination of trade barriers between South Asian countries would increase the welfare level of India. To study the effects of RTAs on trade flows, typically the gravity equation approach is used. In its simplest version, it postulates a relationship between the "mass" (GDP) of two countries and their trade flows. In practical terms, the approach offers a "conditional general equilibrium" relation (Anderson and van Wincoop, 2004) in which bilateral trade is modeled as independent of trade flows with third party countries.

Gravity equations have also been used to measure unobserved trade barriers, to discriminate between theoretical trade models, and to analyze the effects of trade policies (either in an ex-post or ex-ante fashion). ${ }^{11}$ The latter has been subject to critiques and refinements (e.g., Carrère, 2006) among the most important being that for the gravity equation analysis to be appropriate one needs to assume (or "condition on") that the policy changes being

Anderson and van Wincoop (2004); and Feenstra, Markusen, and Rose (2001). aconsidered do not modify the basic relation between countries' masses and their trade flows. ${ }^{12}$ Given the relative small size of South Asian countries in the world markets such an assumption appears not to be problematic for the scenarios considered here. In summary, the general equilibrium approach offers the possibility of answering a richer set of questions but demands data not readily accessible for some of the countries we are interested in. ${ }^{13}$ Although the evaluation of the benefits and limitations of each methodology is beyond the scope of this paper it can be argued that they are complementary rather than substitutes. This paper uses a gravity equation
2938 | $\mathrm{P}$ a g e
council for Innovative Research
A u g u s t 2016
w w w . c i r w or ld. c o m 
International Journal of Management and Information Technology approach and builds on Srinivasan (1994). In particular, it allows the response to trade barriers to differ by source of the goods; treats independently imports and exports of each country pair; and includes all seven members of SAFTA in the analysis. As Bandara and Yu (2003) and Gilbert, Scollay, and Bora (2001) show, welfare and trade volume do not necessarily follow a monotonic relationship and interpreting gravity equation results as describing desirability or welfare can be misleading. ${ }^{15}$ Nevertheless, by providing three different criteria-trade flows, trade balance and customs revenue-the paper provides information on the relative merits of alternative arrangements.

\section{METHODOLOGY}

It is widely acknowledged that computable general Equilibrium (CGE) modeling has become the tool of choice for analysis of a wide range of trade policy issues such as tariffs and non-tariff barriers (NTBs) in both developed and developing countries in a variety of settings. In particular, CGE modeling is useful for analyzing the welfare effects of trade policy that needs to address second-best issues, where there are significant interactions between policy measures for one sector and distortions elsewhere in the economy. Such models have two distinctive features: they incorporate a number of distinct sectors, and the behavioral equations of the model deal with the response of industries and consumers to changes in relative prices (Adams et al., 1998). This development is explained by the capability of CGE models to provide an elaborate and realistic representation of the economy, including the linkages between all agents, sectors and other economies (Brockmeier, 1996) CGE analysis also provides a valuable tool for putting things in an economy-wide

\section{Data Set}

Data will be collected from secondary sources GTAP-7 data base

\section{LIMITATIONS OF THE CGE MODEL}

Instrument

- $\quad$ GTAP-Model

- Variables PAK-INDIA TRADE (Independent variable)

- $\quad$ SAFTA (Dependent Variable)

- Dependent Variables

- Textiles (Dependent Variable)

- Pharmaceuticals (Dependent Variable)

- Automotive parts and engineering(Dependent Variable)

- Agriculture(Dependent Variable)

- Financial an insurance services(Dependent Variable)

- GTAP-Model ((Hertel, 1997) GTAP-7 Data Base

- Data will be analyzed by using GEMS Software

Sectors:

Agriculture

Codes

AUTO

AGRI

TEXTILE

AUTO

PHARMACETICAL

TEXT

INSURANCE AND FINANCIAL SERVICES

PHAR

TRANSPORT AND LOGISTICS

OFI ISR

SOURCE-GTAP-DATA BASE-7

OTPL

\section{Pak-India Trade Model}


1.Pakistan (PK) Pakistan

2. India (IND) India

3.Rest of SouthAsia

\section{Sri Lanka}

Bangladesh

Bhutan

Maldives

Nepal

4. Rest oftheWorld (ROW)

allotherCountries
SHAIKH (2013)

\section{Pak-India Trade Project}

Table-1.Comparative Real GDP-Growth Rate (\%)

\begin{tabular}{|c|c|c|c|c|c|c|}
\hline Region/Country & 2009 & 2010 & 2011 & 2012 & 2013 & 2014(P) \\
\hline WorldGDP & -0.6 & 5.2 & 4.0 & 3.2 & 3.3 & 4.0 \\
\hline EuroArea & -4.4 & 2.0 & 1.4 & -0.6 & -0.3 & 1.1 \\
\hline UnitedStates & -3.1 & 2.4 & 1.8 & 2.2 & 1.9 & 3.0 \\
\hline Japan & -5.5 & 4.7 & -0.6 & 2.0 & 1.6 & 1.4 \\
\hline Germany & -5.1 & 4.0 & 3.1 & 0.9 & 0.6 & 1.5 \\
\hline Canada & -2.8 & 3.2 & 2.6 & 1.8 & 1.5 & 2.4 \\
\hline DevelopingCountries & 6.9 & 9.9 & 8.1 & 6.6 & 7.1 & 7.3 \\
\hline China & 9.2 & 10.4 & 9.3 & 7.8 & 8.0 & 8.2 \\
\hline HongKongSAR & -2.5 & 6.8 & 4.9 & 1.4 & 3.0 & 4.4 \\
\hline Korea & 0.3 & 6.3 & 3.6 & 2.0 & 2.8 & 3.9 \\
\hline Singapore & -0.8 & 14.8 & $\begin{array}{r}5.2 \\
\end{array}$ & 1.3 & 2.0 & 5.1 \\
\hline Vietnam & 5.3 & 6.8 & 5.9 & 5.0 & 5.2 & 5.2 \\
\hline 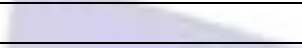 & 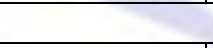 & ASEA & & & & \\
\hline Indonesia & 4.6 & 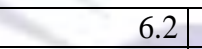 & 6.5 & 6.2 & 6.3 & 6.4 \\
\hline Malaysia & -1.5 & 7.2 & 5.1 & 5.6 & 5.1 & 5.2 \\
\hline Thailand & -2.3 & 7.8 & 0.1 & 6.4 & 5.9 & 4.2 \\
\hline \multirow[t]{2}{*}{ Philippines } & 1.1 & 7.6 & 3.9 & 6.6 & 6.0 & 5.5 \\
\hline & \multicolumn{4}{|c|}{ SouthAsia } & & \\
\hline India & 5.0 & 11.2 & 7.7 & 4.0 & 5.7 & 6.2 \\
\hline Bangladesh & 5.9 & 6.4 & 6.5 & 6.1 & 6.0 & 6.4 \\
\hline SriLanka & 3.5 & 8.0 & 8.2 & 6.4 & 6.3 & 6.7 \\
\hline Pakistan & 0.4 & 2.6 & 3.7 & 4.4 & 3.6 & 4.4 \\
\hline
\end{tabular}


International Journal of Management and Information Technology

Table-2-Growth rate Percentage

\begin{tabular}{|c|c|c|c|c|c|c|c|c|c|c|c|}
\hline Sectors/Sub-Sectors & 2006-07 & 2007-08 & 200 & & 2005 & & 201 & & 201 & 1-12 & 2012- \\
\hline 1.Agriculture & 3.4 & 1.8 & 3.5 & & 0.2 & & 2.0 & & $3 . \overline{5}$ & & 3.3 \\
\hline Crops & 4.4 & - & 5.2 & & & & 1.0 & & 2.9 & & 3.2 \\
\hline ImportantCrops & 6.5 & - & 8.4 & & & & 1.5 & & 7.4 & & 2.3 \\
\hline OtherCrops & 2.1 & 6.0 & 0.5 & & & & 2.3 & & & & 6.7 \\
\hline CottonGinning & - & - & 1.3 & & 7.3 & & & - & & 13. & -2.9 \\
\hline -Livestock & 2.8 & 3.6 & 2.2 & & 3.8 & & 3.4 & & 3.9 & & 3.7 \\
\hline -Forestry & 2.7 & 8.9 & 2.6 & & & & 4.8 & & 1.7 & & 0.1 \\
\hline -Fishing & 0.4 & 8.5 & 2.6 & & 1.4 & & 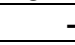 & & 3.8 & & 0.7 \\
\hline IndustrialSector & 7.7 & 8.5 & & - & 3.4 & & 4.7 & & 2.7 & & 3.5 \\
\hline 2.Mining\&Quarrying & 7.3 & 3.2 & & - & 2.8 & & & - & 4.6 & & 7.6 \\
\hline 3.Manufacturing & 9.0 & 6.1 & & - & 1.4 & & 2.5 & & 2.1 & & 3.5 \\
\hline -LargeScale & 9.6 & 6.1 & -6 & & 0.4 & & 1.7 & & 1.2 & & 2.8 \\
\hline -SmallScale & 8.3 & 8.3 & 8.6 & & 8.5 & & 8.5 & & 8.4 & & 8.2 \\
\hline -Slaughtering & 3.2 & 3.3 & 3.8 & & 3.2 & & 3.7 & & 3.6 & & 3.5 \\
\hline ElectricityGeneration\& & $\overline{12.8}$ & $\begin{array}{l}37 . \\
2\end{array}$ & & -12.1 & & 6. & & $\begin{array}{l}66 . \\
4\end{array}$ & 2.7 & & -3.2 \\
\hline 4.Construction & 12. & 15. & & - & 8.3 & & & - & 3.2 & & 5.2 \\
\hline $\begin{array}{l}\text { Commodity Producing } \\
\text { Sector }\end{array}$ & 5.5 & 5.1 & & $\overline{0}$ & 1.8 & & 3.3 & & 3.1 & & 3.4 \\
\hline ServicesSector & 5.6 & 4.9 & 1.3 & & 3.2 & & 3.9 & & 5.3 & & 3.7 \\
\hline 7.Wholesale\&RetailTrade & 5.8 & 5.7 & & - & 1.8 & & 2.1 & & 1.7 & & 2.5 \\
\hline $\begin{array}{ll}\text { 6.Transport, } & \text { Storage } \\
\text { and }\end{array}$ & & 5.5 & 5.0 & & 3.0 & & 2.4 & & 8.9 & & 3.4 \\
\hline 8.Finance\&Insurance & 9.1 & 6.3 & & - & L & & & - & 1.0 & & 6.6 \\
\hline $\begin{array}{l}\text { HousingServices(Ownership } \\
\text { of }\end{array}$ & & 4.0 & 4.0 & & 4.0 & & 4.0 & & 4.0 & & 4.0 \\
\hline GeneralGovernmentService & 2.7 & 0.2 & 5.6 & & 8.0 & & & 14. & & 11. & 5.6 \\
\hline OtherPrivateServices & 4.6 & 5.4 & 6.5 & & 5.8 & & 6.6 & & 6.3 & & 4.0 \\
\hline GDP(fc) & 5.5 & 5.0 & 0.4 & & 2.6 & & 3.7 & & 4.4 & & 3.6 \\
\hline
\end{tabular}

\section{Source-Economic Survey of Pakistan-2012-}

Table .3:Demographicindicators of SAFTA Countries.

\begin{tabular}{|c|c|c|c|c|c|c|c|c|c|}
\hline S.No & Item & Unit & Year/ & Bangladesh & India & Pakistan & Nep & SriLanka & Maldives \\
\hline 1 & 2 & 3 & 4 & 14 & 1 & 16 & 1 & 18 & 19 \\
\hline 1 & Area & $000^{\prime}$ Sq.K & 2010 & 144 & 3287 & 796 & 1 & 66 & 0.3 \\
\hline 2 & Population & Millions & 2010 & 148.70 & 1224. & 173.60 & 30.0 & 20.9 & 0.3 \\
\hline & & Millions & bon & 167.10 & 1385. & 205.20 & 35.1 & 22.3 & 0.4 \\
\hline 3 & Population & $\%$ & $2004^{b}$ & 25.1 & 28.7 & 34.9 & 15.8 & 15.1 & 29.6 \\
\hline & & $\%$ & $2015 \mathrm{~b}$ & 29.9 & 32.0 & 39.6 & 20.9 & 15.7 & 34.8 \\
\hline 4 & Population under & $\%$ & 2010 & 31 & 3 & 35 & 3 & 25 & 34 \\
\hline 5 & Population & $\%$ & 2010 & 5 & 5 & 4 & 4 & 8 & 3.8 \\
\hline 6 & PopulationAnnualGr & $\%$ & $2000-10$ & 1.4 & 1. & 1.8 & 2 & 1.1 & 1.8 \\
\hline 7 & Crude BirthRate & Per 1000 & 2010 & 20 & $\begin{array}{l}2 \\
2\end{array}$ & 27 & $\begin{array}{l}2 \\
4\end{array}$ & 18 & -- \\
\hline 8 & TotalFertility Rate & Birthsper & 2010 & 2.2 & 2. & 3.4 & 2 & 2.3 & \\
\hline 9 & CrudeDeathRate & $\begin{array}{l}\text { Per } \\
\text { 1000Live }\end{array}$ & 2010 & 6 & 8 & 7 & 6 & 7 & -- \\
\hline $\begin{array}{l}1 \\
0 .\end{array}$ & Infant Mortality Rate & $\begin{array}{l}\text { Per } \\
\text { 1000Live }\end{array}$ & 2010 & 38 & $\begin{array}{l}4 \\
8\end{array}$ & 70 & $\begin{array}{l}4 \\
1\end{array}$ & 14 & 33 \\
\hline 1. & $\begin{array}{l}\text { Mortality RateUnder } \\
5 \text { vearsage }\end{array}$ & $\begin{array}{l}\text { Per } \\
\text { 1000Live }\end{array}$ & 2010 & 48 & $\begin{array}{l}6 \\
3\end{array}$ & 87 & $\begin{array}{l}5 \\
0\end{array}$ & 17 & 42 \\
\hline 1 & No.OfDeaths under & $000^{\prime}$ & 1992 & 103 & - & 82 & & -- & -- \\
\hline 1 & LifeExpectancy at & & & & & & & & \\
\hline & Male & Years & 2010 & 68 & 6 & 64 & 6 & 72 & 67 \\
\hline & Female & Years & 2010 & 69 & 6 & 66 & 6 & 78 & 67 \\
\hline & Persons & Years & 2010 & 69 & 6 & 65 & 6 & 75 & 77 \\
\hline
\end{tabular}


Table4:GTAPSubstitutionElasticity's

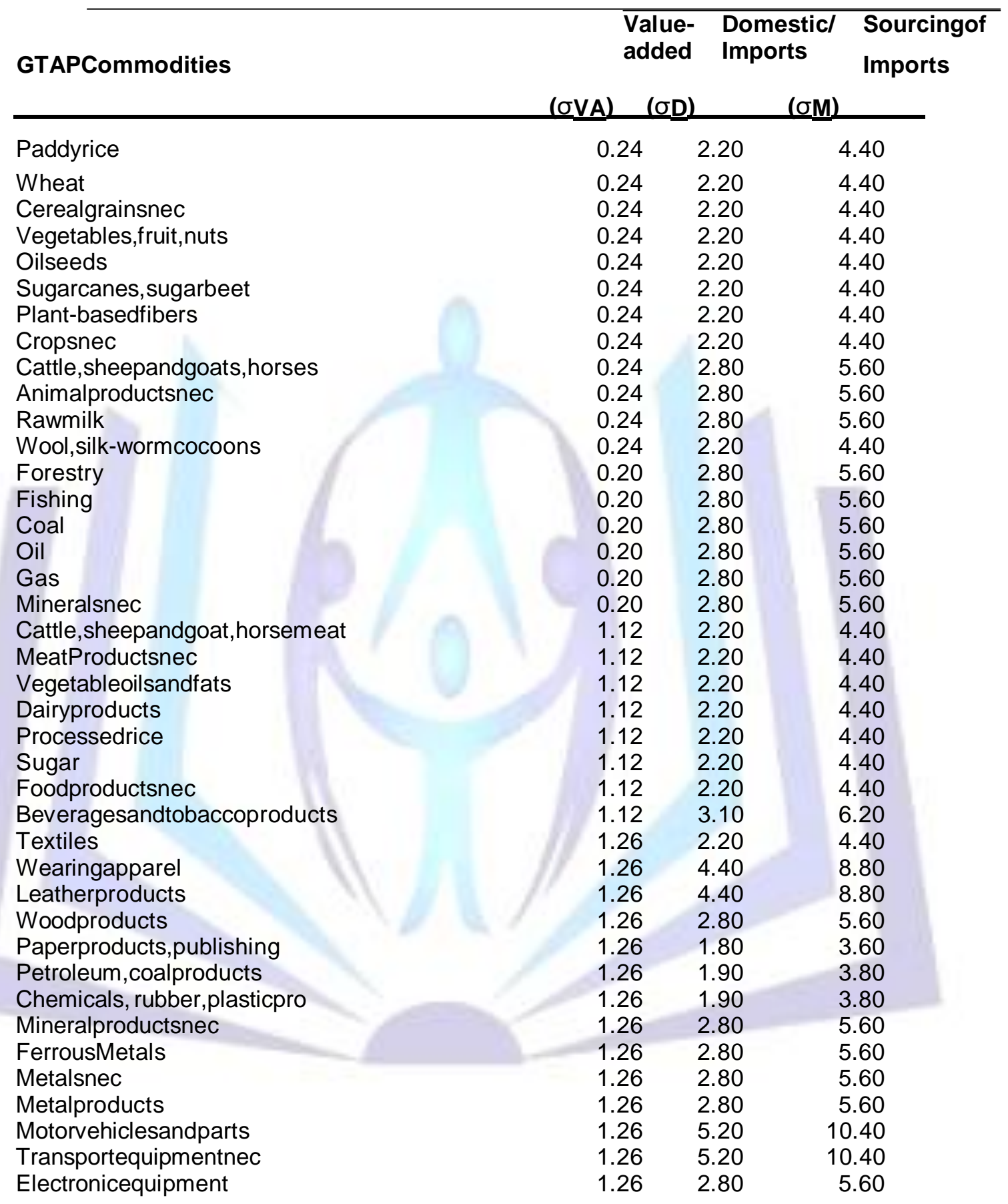




\begin{tabular}{llll} 
Machineryandequipmentnec & 1.26 & 2.80 & 5.60 \\
Manufacturenec & 1.26 & 2.80 & 5.60 \\
Electricity & 1.26 & 2.80 & 5.60 \\
Gasmanufacture,distribution & 1.26 & 2.80 & 5.60 \\
Water & 1.26 & 2.80 & 5.60 \\
Construction & 1.40 & 1.90 & 3.80 \\
Trade,transport & 1.68 & 1.90 & 3.80 \\
Financial,business,recreationalservices(private) & 1.26 & 1.90 & 3.80 \\
Publicadminanddefense,education,health & 1.26 & 1.90 & 3.80 \\
\hline
\end{tabular}

Source:TheGTAPDatabase, Version 7

Table.:5. Pak-India Trade Relationship on SAFTA Model

AggregatedRegions

GTAPRegion

1.Pakistan (PK) Pakistan

2.India (IND) India

3.Rest of SouthAsia

4. Rest oftheWorld (ROW)

Sri Lanka

Bangladesh

Bhutan

Maldives

Nepal

allothercountries

Table6:CommodityAggregation:10SectorsoftheModel

AggregatedCommodity

(1) Agriculture,

Fishing(AGRI)

\section{GTAP Commodity}

Paddy

rice $(\mathrm{p}$

dr)

Wheat

(wht)

Cereal

grainsnec(gro)

Vegetables,

fruit,nuts

$\left(v \_f\right)$ Oilseeds $(0$

sd)

Sugarcane,suger

beet(c_b)Plant

basedfibers(pfb)

Crops (nec)

Bovinecattle,sheepand

goats, horses(ctl)Animalprodu 
International Journal of Management and Information Technology

ctsnec(oap)

Rawmilk(rmk)

Woolsilk- wormcocoons

(wol) Forestry(for)

Fishing
(2) MiningandQuarrying(MINQ)

(3) ProcessedFood (PROF)

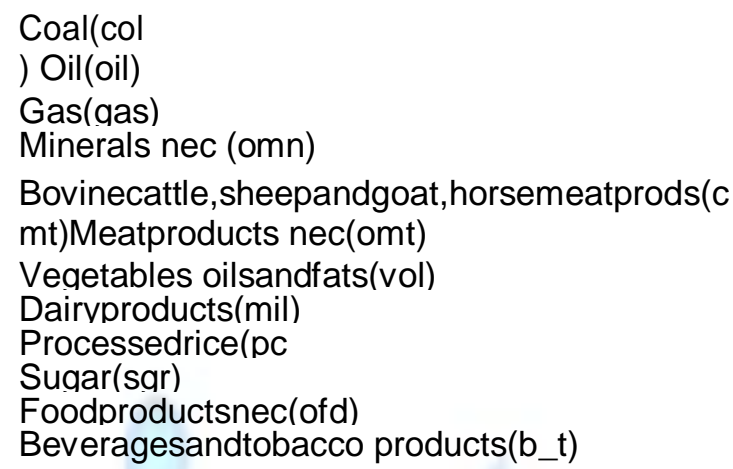

\section{Textiles(tex)}

Wearingapparel(wa leatherproducts Petroleum,coalproducts $\left(p \_c\right)$

(6) Petroleum, Coal Products (PECP)

(7) Machinery and Equipment (MAEQ)

Electronicequipment(ele) Machineryandequipmentnec(ome)

(8) TransportEquipment(TREQ) Motor vehicles andparts (mvh)Transportequ ipmentnec(otn) 
International Journal of Management and Information Technology

(9) Other Heavy Manufactures (OTHM)

(10)Services(SERC)

GTAP-Database-7
Wood products(lum)

Paperproducts,

publishing(ppp)

Chemical,rubber,plasticpr

oducts

(crp)

Mineralproductsnec(nmm)

Ferrous

metals

(i_s)Metal

snec $(\mathrm{nfm}$

Metalproducts

Manufacturesnec(omf)

Electricity(ely)

Gas,manufacture, distribution(gdt)

Water(wtr)

Construction(c

ns)

Trade,transport(t_

t)

Financial,business, recreationalservices (osp)Public adminanddefence,education, health(osg)D welling (dwe)

Table10:Experiment-1

15PercentUniformImportTariffs

EstimatedPercentageChangesinRegionalOutputandTrade

Sector

IND

PAK

XSA

XWA

(a)IndustryOutput (In Millions)

\begin{tabular}{|l|c|c|c|c|}
\hline AGRI & $\mathbf{- . 0 2}$ & $\mathbf{0 . 7 7}$ & 0.07 & -0.03 \\
\hline PHAR & $\mathbf{3 . 7 8 6 1}$ & $\mathbf{1 . 3 4}$ & -0.06 & 0.05 \\
\hline AUT & $\mathbf{4 . 0 2}$ & $\mathbf{1 . 5 7}$ & 0.05 & 0.03 \\
\hline TEXT & $\mathbf{1 . 4 5 . 0 3}$ & $\mathbf{2 . 6 0}$ & 0.01 & 0.11 \\
\hline OFIISR & $\mathbf{- 0 . 1 3}$ & $\mathbf{8 . 4 3}$ & -0.11 & -0.20 \\
\hline OTPL & $\mathbf{- 0 . 0 1}$ & $\mathbf{2 0 . 5 5}$ & 0.00 & -0.03 \\
\hline (b) Export & (In Millions) \\
\hline AGRI & $\mathbf{1 . 4 4}$ & $\mathbf{1 . 0 0}$ & 0.07 & -0.03 \\
\hline PHAR & $\mathbf{0 . 0 1}$ & $\mathbf{0 . 9 0}$ & -0.06 & 0.05 \\
\hline AUT & $\mathbf{0 . 1 9}$ & $\mathbf{- 1 . 1 4}$ & 0.05 & 0.03 \\
\hline TEXT & $\mathbf{- 0 . 1 6}$ & $\mathbf{6 . 7 9}$ & 0.01 & 0.11 \\
\hline OFIISR & $\mathbf{- 0 . 2 8}$ & $\mathbf{2 . 4 8}$ & -0.11 & -0.20 \\
\hline OTPL & $\mathbf{- 0 . 0 0}$ & $\mathbf{2 . 5 7}$ & 0.00 & -0.03 \\
\hline
\end{tabular}


Tariff Rates

$5 \%$ SAFTA

$15 \%$ XWA

$5 \%$ XSA

15 MFN

Table 20: Impact of Pak-India Trade on Employment (000 million)

\begin{tabular}{|l|l|l|}
\multicolumn{1}{l}{ Sector } & \multicolumn{1}{l}{ IND } & \multicolumn{1}{c}{ PAK } \\
\hline AGRI & $\mathbf{3 . 8 9}$ & $\mathbf{3 . 8 1 . 1 2}$ \\
\hline PHAR & $\mathbf{1 9 . 1 1}$ & $\mathbf{1 5 . 3 1}$ \\
\hline AUTO & $\mathbf{5 . 8 8}$ & $\mathbf{7 . 5 6}$ \\
\hline TEXT & $\mathbf{8 . 4 6}$ & $\mathbf{1 1 . 1 0}$ \\
\hline OSIISR & $\mathbf{7 . 7 2}$ & -4.21 \\
\hline OTPL & $\mathbf{9 . 6 8}$ & $\mathbf{- 3 . 2 2}$ \\
\hline
\end{tabular}

\section{Source-GTAP-7}

From the Above Table it indicate that if we are going to initiate the trade with India there will be change in the employment in Agriculture, Pharmaceutical, Auto, Textile, Insurance and logistic and transport sector. Negative sign shows that the sectors where Pakistan's not getting benefit, otherwise India has absolutely advantage in the sectors of OSIISR and OTPL sector. The overall results suggests that on MFN status with India there will be positive change in Employment.

\section{Conclusions}

Thesimulationresultspresentedand analyzedheredemonstratetheimportance ofexperimentaldesigns, andthe usefulnessoftheglobal CGEmodelingframeworkforexaminingtheimpactsofthe differenttypesoftradepolicy reforms for Pakistan.TheresultssuggestthatPakistanwouldexperiencethehighestwelfaregain if underthecombinedpolicy reform ofthe SAFTAcum 15percentuniform externaltariffswhiletheSAFTAonitsowngivesthesecondhighest welfare gains.SAFTAallowsthe participatingcountriestoachieve largereconomiesof scalein production, attain specialization,increasecompetitivenessand diversifytheirexport basket,thusassistingdomesticeconomicreform. Therefore,harmonizingeconomicpolicies amongneighboringcountriesmustreceivehigher priorityinthepolicy makingprocess. Although,simulationresultsare highlysensitivetothe underlying data andassumptionsregardingthe referencescenarios, theresults clearly providean assessment of the implicationsof SAFTA. According to the simulation results suggests that there will be positive impact on PAK-INDIA trade on GDP, EXPORT, IMPORT and EMPLOYMENT under various scenarios, of tariff rates should applied like, MFN. $15 \%, 10 \%$ and $8 \%$. Pakistan's has welfare gain of tariff rate $15 \%$ and $10 \%$ respectively but on $8 \%$ tariff results shows that there will be negative impact on the selected sectors.

\section{References}

1. Centre for Monitoring Indian Economy. (2004). Annualreporton Corporate Sector.

2. Government ofPakistan(Variouslssues).Censusof ManufacturingIndustries, Islamabad: Federal Bureauof Statistics.

3. GovernmentofPakistan(Variouslssues).EconomicSurvey,andlslamabad:EconomicAdvisor'sWin g,Ministryof Finance.

4. Government ofPakistan(Various Issues). Monthly Statistical Bulletin, and Islamabad: Federal Bureauof Statistics

5. Government ofPakistan (Variouslssues). Pakistan CustomandTariffs year Booklslamabad: Central Board of Revenue

6. ( 
C

B)

7. Governmentof India,AnnualReport 2003-04,Department of Commerce and trade.

8. Pakistangulf economist December.(2002). reportBy M.EJALBANI,Director, EPB.

9. Governmentof India,(Various Issues). Economic Survey,New Delhi: Economic Division, Ministryof Finance.

10. Government of India, directorate General of foreign Trade, Ministry of Commerce. [Online] Available:

11. www.dgft.delhi .nic.in.

12. International FinancialStatistics, CD-ROM.(2004). InternationalMonetary Fund,WashingtonDC. Ju,JiandongandKalaKrishna.(1998).FirmBehaviorandMarketAccessinaFreeTradeAreawithRules ofOrigin.

13. NBER working Paper, No. 6857.

14. Panagariya,A. (1994).East Asia and theNew Regionalism.World Economy, 17:6, 817-39.

15. Panagariya,A.(1995).RethinkingtheNewRegionalism',PaperPresentedattheUNDPWorldBankTra deExpansion

16. Conference,January,WorldBank,WashingtonDC.

17. Panagariya,A.(2000).PreferntialTradeLiberalization:TheTraditionalTheoryandNewDevelopments .Journalof

18. Economic Literature,38, June, 287-331.

19. Purcell, Garry. (2004a). Analyzing the Economic Welfare Consequences of A Fare Trade Agreement: Partial

20. EquilibriumMethodsforIndustry LevelStudies, Manuscript Presented atWorld bankDhaka Office.

21. Purcell,Garry.(2004b).AnIndia-

BangladeshFreeTradeAgreement?SomePotentialEconomicCostsandbenefits, presented during theworkshop heldatWorldBank, Islamabad Office.

22. Summers,L.(1991).RegionalismandtheWorldTradingSystems,FederalReserveBankofKansasCity ,Policy 

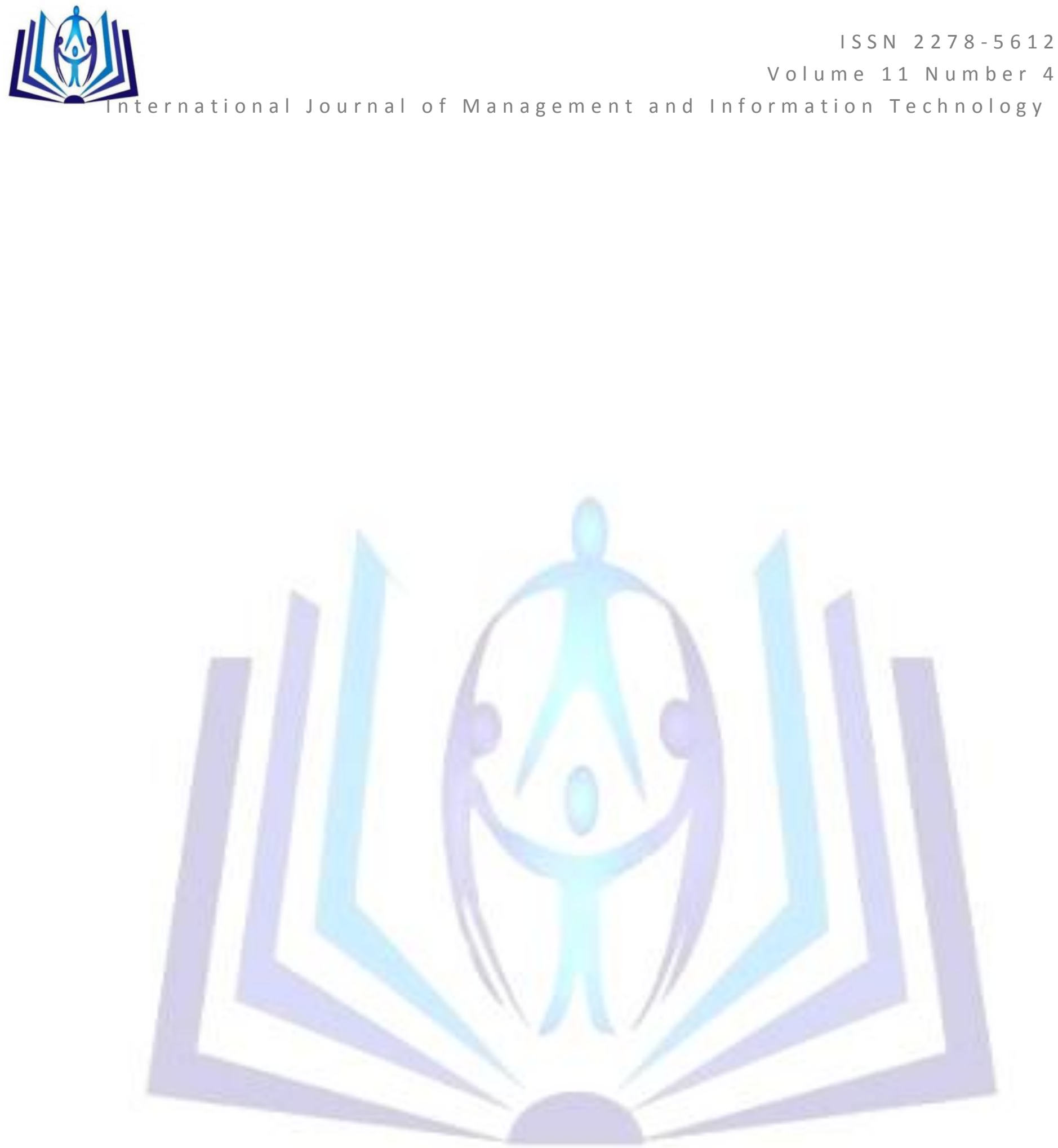